\title{
Performance of Fall-sown Onion Cultivars Using Four Seeding Dates
}

\author{
Christopher S. Cramer ${ }^{1}$ \\ Department of Agronomy and Horticulture, Box 30003, MSC 3Q, New Mexico State University, Las \\ Cruces, NM 88003-0003
}

\begin{abstract}
AdDitional index wORDs. Allium cepa, bolting, bulb maturity, fusarium basal rot, pink root, scape production, seedstalk production, single centers, yield

Abstract. As fall-sown onions are seeded earlier, an increase in premature seedstalk (bolting) incidence is observed for bolting-susceptible cultivars. The mechanism of resistance for bolting-resistant cultivars is not well known. Four fall-sown cultivars (Daybreak, NuMex Mesa, NuMex Sweetpak, Texas Early White), that differed in their bolting susceptibility, were seeded on four separate dates in September, each one week apart, in Las Cruces, N.M., to observe their growth and performance at each seeding date. Plant height and leaf number were measured monthly throughout the growing season from 10 plants in each plot. Prior to harvest, the number of plants that bolted were counted. When $80 \%$ of the plants in a plot were mature, the bulbs were harvested and the maturity date, disease resistance, bulb yield, and percentage of single centers were recorded. In general, earlier seeding dates resulted in larger plants with more leaves than later seeding dates when compared early in the growing season. By harvest time, plants from later seeding dates were comparable in height and had produced more leaves than earlier seeded plants. Plant height of 'NuMex Mesa' (bolting resistant) was less than the plant height of bolting-susceptible cultivars. Bolting-resistant and boltingsusceptible cultivars produced similar numbers of leaves throughout the season. The mechanism of bolting resistance for 'NuMex Mesa' may be a smaller plant size and/or a greater plant size required for receptivity to bolting-inducing temperatures as compared to bolting-susceptible cultivars. In general, cultivars exhibited less bolting, later maturity dates, and an increase in bulb yield with a delay in seeding.
\end{abstract}

During the months of June and July, New Mexico supplies most summer nonstorage onions (Allium cepa L.) grown in the United States (U.S. Department of Agriculture, 2000). Most onion cultivars grown in New Mexico are short- or intermediate-day in their bulbing daylength response. The fall-seeded crop is planted in late September and early October, overwintered, and harvested in late May and June of the following year. Temperatures are high enough during the winter season that onions can be overwintered without substantial plant losses. Conversely, temperatures during the winter season are low enough to induce premature flowering or bolting, and yield loss occurs unless bolting resistance is present. Planting date recommendations for fall-seeded cultivars are based on bolting resistance (Corgan et al., 2000). Boltingsusceptible cultivars are seeded in early October to reduce bolting. As cultivars are seeded later in October, plants are smaller in size going into the winter season and these plants are more susceptible to winter injury than earlier-seeded, larger-sized plants (Corgan et al., 2000). However, as cultivars are seeded earlier in the fall season, larger plants are produced before the winter season, less winter injury occurs, but more bolting is observed. Other researchers have observed increases in bolting with earlier seeding dates of fall-sown onions (Allen et al., 1978; Brewster and Salter, 1980; Holdsworth, 1945; Matlob and El-Haber, 1979; Passam et al., 1995; Salter and James, 1975). Determining the proper date for fall seeding to minimize winter injury and bolting, while maximizing yield, can be difficult and is cultivar and environment dependent. Bolting-resistant cultivars have reduced bolting incidence and winter injury, increased bulb yield, and allowed for earlier seeding.

Onion flower induction is caused by low temperatures after a

Received for publication 11 Oct. 2002. Accepted for publication 4 Apr. 2003. This research was funded in part by the NMSU Agricultural Experiment Station and the New Mexico Dry Onion Commission.

${ }^{1}$ Assistant professor of horticulture. juvenile phase of development from seed (Thompson and Smith, 1938). In the first year from seed, onion plants will produce a bulb and enter a dormancy period. Once dormancy period is completed, the apical vegetative meristem will differentiate into a reproductive meristem and an axillary vegetative meristem. Both meristems will begin to develop and elongate. The reproductive meristem will form the flowering inflorescence in the second year after seeding. Onion plants will form a seedstalk in the first year if they reach a critical size and then receive thermo induction. A reduction in plant size lowers the bolting percentage of a bolting-susceptible cultivar (Sanders and Cure, 1996). The sensitivity to low temperatures increases with plant size (Hartsema, 1947; Heath and Mathur, 1944; Jones and Emsweller, 1937; Rabinowitch, 1979; Thompson and Smith, 1938).

Several methods have been used to determine onion plant age and the critical size at which plants can be induced to bolt. Since leaf initiation rate is constant in a given environment (Brewster, 1983; 1987), leaf number has been used to determine a plant's age (Rabinowitch, 1990). Some studies with seedlings reported that 10 to 14 leaves were needed before flowering could be initiated (Gregory, 1936; Heath and Mathur, 1944). The number of leaves required before floral initiation can occur varies among studies. Heath and Mathur (1944) observed reproductive differentiation for 'Alisa Craig' as early as 12 leaves with most plants averaging 13.6 leaves. Ito (1956) reported that a minimum of 11 to 12 leaves of 'Yamaguch-kokoda' and 'Awaji-chu-kokoda' was required for floral initiation. Plant mass has also been used to determine the plant size required to induce bolting. For stored sets of 'Alisa Craig', a minimum size of 4 to $7 \mathrm{~g}$ fresh weight per bulb was required for inflorescence initiation (Heath et al., 1947). Brewster (1985) determined that a critical dry plant weight of $0.45 \mathrm{~g}$ and $0.06 \mathrm{~g}$ was needed to get floral initiation of 'Senshyu Semi-Globe Yellow' and 'Rijnsburger', respectively.

Early seeded plants produced more leaves and taller plants 
than later seeded plants (Moursi et al., 1975). Earlier seeding dates resulted in fewer winter plant losses (Moursi et al., 1975) while later seeding dates resulted in higher winter plant losses (Allen et al., 1978). When bolting was not a problem, earlier seeding dates resulted in larger bulbs and higher yields (Allen et al., 1978; Holdsworth, 1945; Passam et al., 1995; Richwine, 1990; Salter and James, 1975). When bolting was a problem, later seeding dates produced a higher yield than earlier seeding dates due to the yield reduction caused by bolting (Matlob and El-Haber, 1979; Salter and James, 1975). Earlier seeding dates produced a higher percentage of multi-centered bulbs than later plantings (Matlob and El-Haber, 1979; Rabinowitch, 1979). This difference was likely caused by larger plants that were being produced at the earlier seeding dates. Earlier seeding dates resulted in earlier bulb maturity (Salter and James, 1975) while later seeding dates resulted in later maturity (Almanza-Sandoval and Wall, 2000; Moursi et al., 1975).

My objectives were to determine 1) the effect of fall seeding date on bulb maturity, bolting resistance, disease incidence, and bulb yield and quality; 2) if bolting resistance is changed with seeding dates; 3) if these cultivars differ in plant growth; and 4) plant growth is inversely correlated with bolting resistance.

\section{Materials and Methods}

Four cultivars were selected because of their difference in bolting susceptibility. Based on results from variety trials, 'NuMex Mesa' (Corgan, 1996) was highly resistant to bolting, 'Daybreak' was moderately resistant to bolting, 'NuMex Sweetpak' (Wall and Corgan, 1999) was moderately susceptible to bolting, and 'Texas Early White' was highly susceptible to bolting (Cramer et al., 1998, 2000, 2001, 2002). Each cultivar was seeded on 9 , 16, 23, and 30 Sept. 1999 and 8, 15, 22, and 29 Sept. 2000. The experiment was arranged as a split plot with seeding date being the whole plot factor and cultivar being the subplot factor. Within each seeding date, cultivars were randomized four times and arranged in a completely randomized block design. Plots consisted of two rows on raised, shaped beds that were $5.5 \mathrm{~m}$ in length and $1 \mathrm{~m}$ wide (center to center). Plots were separated by alleys that were $0.6 \mathrm{~m}$ in length. Side border beds and end bed border plots surrounded the experiment. About $3 \mathrm{~g}$ of seed per cultivar was planted in each plot. The plants were thinned to $10 \mathrm{~cm}$ between plants within the row on 10 (first and second seedings) and 16 (third and fourth seedings) Nov. 1999, and 26 Oct. (first, second, and third seedings) and 13 Nov. (fourth seeding) 2000. At 90, 120 , $150,180,210$, and $241 \mathrm{~d}$ after seeding, 10 plants were randomly selected from each plot and the plant height from the soil surface to the longest green leaf and the number of visible green leaves were measured for each plant. An average plant height and leaf number were calculated for each plot.

Plants were grown using standard cultural practices for growing fall-planted onions in southern New Mexico (Corgan et al., 2000). Plots were irrigated as needed using drip irrigation lines $(0.2 \mathrm{~m}$ between emitters) placed $10 \mathrm{~cm}$ deep. Plants were fertilized through the drip lines with $30 \mathrm{mg} \cdot \mathrm{kg}^{-1}$ of URAN (urea and ammonium nitrate) $32(32 \mathrm{~N}-0 \mathrm{P}-0 \mathrm{~K})$ as needed. Prior to seeding, diammonium phosphate $(18 \mathrm{~N}-20.1 \mathrm{P}-0 \mathrm{~K})$ was applied at a rate of $46 \mathrm{~kg} \cdot \mathrm{ha}^{-1}$. Immediately after seeding, DCPA (Dacthal) was applied at a rate of $1.5 \mathrm{~kg} \cdot \mathrm{ha}^{-1}$. During the growth of the crop, permethrin (Karate) was applied at a rate of $42.7 \mathrm{~mL} \cdot \mathrm{ha}^{-1}$ a.i. to control onion thrips (Thrips tabaci Lindeman) populations.

Plots were harvested when $80 \%$ of the plant tops had fallen over. The number of plants that had bolted out of the first 80 plants within the plot was recorded. The date at which all plants would be mature was estimated for each plot as the maturity date. Plants in the front $1.5 \mathrm{~m}$ and back $1.5 \mathrm{~m}$ of the plot were not harvested. Only the plants in the center $2.5 \mathrm{~m}$ of the plot were harvested. The total number of bulbs was counted. The root systems of 30 randomly selected bulbs per plot were rated for pink root [causal agent, Phoma terrestris (E.M. Hans.) Gorenz, J.C. Walker, \& R.H. Larson] severity using a subjective rating of 1 (no pink roots) to 9 (heavily infected roots). The basal plates of 30 randomly-selected bulbs were cut transversely and the severity of fusarium basal rot (FBR) [causal agent, Fusarium oxysporum Schlechtend.: Fr f. sp. cepae (H.N. Hans.) W.C. Snyder \& H.N. Hans.] was rated using a subjective rating of 1 (no diseased tissue) to 9 (70\% or more diseased tissue). An average pink root rating and FBR rating were calculated. The percentage of diseased bulbs (either pink root or FBR) was calculated using the rated bulbs. Bulbs infected with FBR remained at the plot and were not used in the calculation of bulb yield per plot.

Bulb tops and roots of all plants were clipped. Bulbs were placed in burlap sacks and were cured at field conditions for 4 d. After curing, the total bulb fresh weight was measured for each plot. Afterwards, bulbs were graded to remove culls (bulbs $<38 \mathrm{~mm}$ in diameter, diseased, split, and double bulbs). The number of culls was subtracted from the total number of bulbs to yield the number of marketable bulbs. The marketable bulbs per plot were weighed to measure the marketable fresh weight. The percentage of marketable yield was calculated by dividing the marketable weight by the total weight. The marketable bulb weight per hectare was determined using marketable bulb weight per plot and using $1 \mathrm{~m}$ bed width (center to center). The average bulb weight was calculated. Thirty bulbs per plot were cut transversely at the vertical center of the bulb. The percentage of bulbs with single growing points was determined by counting the

Table 1. Plant height and leaf number per plant at 90, 120, 150, 180, and $210 \mathrm{~d}$ after seeding for cultivars grown during the 1999-2000 and 2000-2001 growing seasons.

\begin{tabular}{|c|c|c|c|c|c|}
\hline \multirow[b]{2}{*}{ Year } & \multicolumn{5}{|c|}{ Days after seeding } \\
\hline & 90 & 120 & 150 & 180 & 210 \\
\hline & \multicolumn{5}{|c|}{ Plant ht $(\mathrm{cm})$} \\
\hline 1999-2000 & 14.7 & 15.8 & 22.8 & 41.1 & 68.0 \\
\hline \multirow[t]{3}{*}{ 2000-2001 } & 20.0 & 19.9 & 26.7 & 50.2 & 77.7 \\
\hline & $* * *$ & $* * *$ & $* * *$ & $* * *$ & $* * *$ \\
\hline & \multicolumn{5}{|c|}{ Leaf no. } \\
\hline \multirow{3}{*}{$2000-2001$} & 2.9 & 2.9 & 3.7 & 5.8 & 8.2 \\
\hline & 3.6 & 3.4 & 4.2 & 6.7 & 9.0 \\
\hline & $* * *$ & $* * *$ & $* * *$ & $* * *$ & $* * *$ \\
\hline
\end{tabular}

${ }^{* * *}$ Significant at $P=0.001$. 
number of bulbs with a single growing point (single center) or multiple growing points located within $13 \mathrm{~mm}$ from the center of the bulb and dividing by 30 .

Plant height and leaf number trait means were calculated for each year, observation time, seeding date, cultivar, and their interactions using SAS for MacIntosh v. 6.12 (SAS Institute, Inc., Cary, N.C.) Trait means for maturity date, bolting percentage, disease resistance, bulb yield, and percentage of single centers were calculated for each year, seeding date, cultivar, and their interactions using SAS. A Fisher's protected LSD mean separation test was conducted and the value at $\alpha=0.05$ comparisonwise was reported for traits in which more than two means were being compared and significant differences between cultivars were observed.

\section{Results and Discussion}

Because the 2000-2001 test year (TY) was warmer than 19992000, plant heights and leaf numbers per plant were greater (Table 1). Plants that were grown in the 1999-2000 TY matured earlier than plants in the 2000-2001 TY (Table 2). The early maturity in the 1999-2000 TY was associated with $15 \mathrm{~d}$ of a maximum day air temperatures in excess of $32^{\circ} \mathrm{C}$ in the months of April and May as compared to $7 \mathrm{~d}$ in 2000-2001 TY (New Mexico Climate Data). High day air temperatures speed onion maturity. Pink root and FBR severity and incidence were higher in the 2000-2001 TY than in the 1999-2000 TY (Table 2). Marketable bulb yield and average bulb size were greater in the 2000-2001 TY than in the 1999-2000 TY (Table 2). The increase in disease severity and incidence and in bulb yield and size from the 1999-2000 TY to the 2000-2001 TY was likely due to the later bulb maturity in the 2000-2001 TY. With more time to grow, plants produced larger bulbs and higher yields and are exposed to more disease pressure in the warmer soils. The percentage marketable bulb yield and percentage of single centered bulbs were higher in the 1999-2000 TY than in the 2000-2001 TY (Table 2). The percentage of single centered bulbs is often negatively correlated with average bulb size. As bulb size increases, the percentage of single centered bulbs decreases. Although magnitude differences in trait means existed between years, the relative rank of trait values within each year was similar between years. For this reason, data from both test years were combined and trait means averaged across years will be presented and discussed.

Seeding at the earliest date resulted in the longest time for plants to reach maturity (251.5 d) as compared to $243.5 \mathrm{~d}$ for plants seeded on the third or fourth seeding dates (Table 3 ). When comparing the actual maturity date, plants that were seeded on the first or second date matured one week earlier than plants seeded on the third date, and $10 \mathrm{~d}$ earlier than plants seeded on the fourth date (Table 3). Almanza-Sandoval and Wall (2000), Moursi et al. (1975), and Salter and James (1975) also observed a delay in bulb maturity with a later seeding. Plants that were seeded on the first three dates exhibited the same FBR severity that was lower than the FBR severity of plants seeded on the last date (Table 3). The FBR incidence was similar for plants seeded at any of the dates (Table 3). The FBR severity and incidence is often lower for early maturing cultivars than for later maturing cultivars (Cramer et al., 2001, 2002). For the earliest maturing cultivars, soil temperatures in May have not remained at optimum temperature for disease development for long enough periods of time to cause higher disease incidence and severity.

At the earliest seeding date, plants of 'NuMex Mesa' had a lower bolting incidence than the other cultivars tested (Table 4). 'Day-

Table 2. Pink root severity rating and incidence, fusarium basal rot severity and incidence, percentage marketable yield, marketable bulb yield, percentage of single centers, maturity (days after seeding, actual date), and seedstalk percentage for cultivars grown during the 1999-2000 and 2000-2001 growing seasons.

\begin{tabular}{|c|c|c|c|c|}
\hline Year & $\begin{array}{c}\text { Pink root } \\
\text { severity ratingz }\end{array}$ & $\begin{array}{c}\text { Pink root } \\
\text { incidence }(\%)^{y}\end{array}$ & $\begin{array}{c}\text { Fusarium basal } \\
\text { rot severity rating }\end{array}$ & $\begin{array}{c}\text { Fusarium basal } \\
\text { rot incidence }(\%)^{\mathrm{w}}\end{array}$ \\
\hline 1999-2000 & 2.0 & 73.4 & 1.9 & 33.3 \\
\hline \multirow[t]{3}{*}{ 2000-2001 } & 2.3 & 84.5 & 2.1 & 41.3 \\
\hline & $* * *$ & $* * *$ & $*$ & $* * *$ \\
\hline & \multicolumn{2}{|c|}{ Marketable yield } & Avg bulb & Single \\
\hline Year & $(\%)^{v}$ & $\left(\mathrm{Mg} \cdot \mathrm{ha}^{-1}\right)^{\mathrm{u}}$ & wt $(g)^{t}$ & centers $(\%)^{\mathrm{s}}$ \\
\hline 1999-2000 & 92 & 40.6 & 268 & 52.8 \\
\hline \multirow[t]{3}{*}{ 2000-2001 } & 87 & 67.7 & 421 & 35.8 \\
\hline & $* * *$ & $* * *$ & $* * *$ & $* * *$ \\
\hline & \multicolumn{2}{|c|}{ Maturity $^{r}$} & Seedstalks & \\
\hline Year & Days after seeding & Date $^{x}$ & $(\%)^{\mathrm{q}}$ & \\
\hline 1999-2000 & 244.6 & May 21 & 8.4 & \\
\hline 2000-2001 & $\begin{array}{c}247.6 \\
* * *\end{array}$ & $\begin{array}{c}\text { May } 24 \\
* * *\end{array}$ & $\begin{array}{l}8.4 \\
* * *\end{array}$ & \\
\hline
\end{tabular}

zRoot systems of 30 bulbs per plot were rated based on a scale of 1 (no infected roots) to 9 (completely infected roots).

yPercentage of bulbs with pink root.

${ }^{x}$ Cut basal plates of 30 bulbs per plot were rated based on a scale of 1 (no disease tissue) to 9 ( $70 \%$ or more of basal plate decayed).

wPercentage of bulbs with fusarium basal plate rot.

vercentage of marketable yield was calculated by dividing marketable bulb weight by total bulb weight.

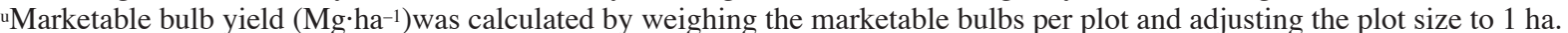

tAverage bulb weight was calculated by dividing the marketable bulb weight by the number of marketable bulbs.

sThe percentage of bulbs with single centers (single growing point) was determined by cutting each bulb transversely at the vertical center and measuring the number of growing points that extended $1.3 \mathrm{~cm}$ beyond the bulb's center.

rA plot was considered matured when $80 \%$ of the tops were down.

qThe percentage of seedstalks was determined at harvest and calculated by dividing the number of plants with seedstalks by the total number of plants per plot.

***: Significant at $P=0.001$. 
Table 3. Maturity, and fusarium basal rot severity and incidence of onion cultivars for each seeding date.

\begin{tabular}{|c|c|c|c|c|}
\hline \multirow[b]{2}{*}{$\begin{array}{l}\text { Seeding } \\
\text { date }\end{array}$} & \multicolumn{2}{|c|}{ Maturity } & \multicolumn{2}{|c|}{ Fusarium basal rot } \\
\hline & $\begin{array}{c}\text { Days after } \\
\text { seeding }\end{array}$ & Date $^{z}$ & $\begin{array}{c}\text { Severity } \\
\text { ratingy }\end{array}$ & $\begin{array}{c}\text { Incidence } \\
(\%)^{\mathrm{x}}\end{array}$ \\
\hline Sept. 9th & 251.5 & 18 May & 2.0 & 34.6 \\
\hline Sept. 16th & 245.8 & 19 May & 2.0 & 32.6 \\
\hline Sept. 23rd & 243.5 & 24 May & 2.0 & 39.5 \\
\hline Sept. 30th & 243.5 & 31 May & 2.3 & 42.5 \\
\hline Mean & 246.1 & 22 May & 2.0 & 37.3 \\
\hline $\operatorname{LSD}(5 \%)$ & $0.5^{* * * *}$ & $0.5^{\text {**** }}$ & $0.2^{*}$ & NS \\
\hline
\end{tabular}

${ }^{2} \mathrm{~A}$ plot was considered matured when $80 \%$ of the tops were down. yCut basal plates of 30 bulbs per plot were rated based on a scale of 1 (no disease tissue) to 9 ( $70 \%$ or more of basal plate decayed).

xPercentage of bulbs with fusarium basal plate rot.

Ns,*****Nonsignificant or significant at $P=0.05$ or 0.001 , respectively. break' had less bolting than 'NuMex Sweetpak' and 'Texas Early White'. The bolting incidence of 'Daybreak', 'NuMex Sweetpak', and 'Texas Early White' decreased at later plantings. At the last seeding date, the bolting incidence of 'NuMex Sweetpak' and 'Texas Early White' would be commercially acceptable. Onion growers commonly delay the seeding of bolting-susceptible cultivars to minimize bolting incidence (Corgan et al., 2000). At each seeding date, 'NuMex Mesa' exhibited less bolting than 'NuMex Sweetpak' and 'Texas Early White'. The bolting percentage of 'NuMex Mesa' was near zero at all seeding dates.

At the earliest seeding date, cultivars did not differ in their pink root severity and incidence (Table 4). At the second and third seedings, plants of 'Daybreak' had a higher pink root severity than plants of 'NuMex Mesa' and 'Texas Early White' (Table 4). At the last seeding, plants of 'Texas Early White' exhibited a lower pink root severity (1.9) and incidence than plants of the other cultivars (Table 4). 'Daybreak' had a higher pink root incidence

Table 4. Performance of four fall-seeded onion cultivars seeded on four different dates.

\begin{tabular}{|c|c|c|c|c|c|c|c|}
\hline \multirow[b]{3}{*}{ Cultivar } & \multirow{3}{*}{$\begin{array}{c}\text { Seedstalks } \\
(\%)^{\mathrm{z}}\end{array}$} & \multicolumn{2}{|c|}{ Pink root } & \multirow{2}{*}{\multicolumn{2}{|c|}{$\begin{array}{c}\text { Marketable } \\
\text { yield }\end{array}$}} & \multirow{3}{*}{$\begin{array}{c}\text { Avg bulb } \\
\text { wt } \\
(g)^{u}\end{array}$} & \multirow{3}{*}{$\begin{array}{c}\text { Single } \\
\text { centers } \\
(\%)^{t}\end{array}$} \\
\hline & & \multirow{2}{*}{$\begin{array}{c}\text { Severity } \\
\text { ratingy }\end{array}$} & \multirow{2}{*}{$\begin{array}{c}\text { Incidence } \\
(\%)^{\mathrm{x}}\end{array}$} & & & & \\
\hline & & & & $(\%)^{\mathrm{w}}$ & $\left(\mathrm{Mg} \cdot \mathrm{ha}^{-1}\right)^{\mathrm{v}}$ & & \\
\hline \multicolumn{8}{|l|}{ First seeding (9 Sept.) } \\
\hline NuMex Mesa & 1.9 & 2.1 & 76.3 & 91 & 60.8 & 355 & 44.6 \\
\hline Daybreak & 10.2 & 2.1 & 79.2 & 91 & 57.5 & 350 & 38.3 \\
\hline NuMex Sweetpak & 25.3 & 2.3 & 89.0 & 88 & 47.5 & 360 & 45.4 \\
\hline Texas Early White & 34.2 & 2.1 & 86.4 & 88 & 39.8 & 342 & 49.3 \\
\hline Mean & 17.9 & 2.1 & 82.7 & 89 & 51.8 & 352 & 44.3 \\
\hline $\operatorname{LSD}(5 \%)$ & $6.7^{* * *}$ & NS & NS & NS & $16.2^{* * *}$ & NS & NS \\
\hline \multicolumn{8}{|c|}{ Second seeding (16 Sept.) } \\
\hline NuMex Mesa & 0.8 & 2.0 & 69.6 & 89 & 51.5 & 304 & 33.8 \\
\hline Daybreak & 3.9 & 2.2 & 84.6 & 94 & 62.7 & 352 & 44.6 \\
\hline NuMex Sweetpak & 14.7 & 2.1 & 79.2 & 90 & 51.2 & 346 & 43.8 \\
\hline Texas Early White & 12.7 & 1.8 & 64.6 & 94 & 44.4 & 320 & 53.8 \\
\hline Mean & 8.0 & 2.0 & 74.5 & 92 & 52.4 & 330 & 43.7 \\
\hline $\operatorname{LSD}(5 \%)$ & $5.7^{* * * *}$ & $0.2^{* *}$ & $14.4^{*}$ & NS & $8.5^{* *}$ & NS & $12.2^{*}$ \\
\hline \multicolumn{8}{|l|}{ Third seeding (23 Sept.) } \\
\hline NuMex Mesa & 0.8 & 2.0 & 72.5 & 94 & 60.3 & 324 & 33.8 \\
\hline Daybreak & 2.0 & 2.3 & 83.3 & 90 & 54.6 & 348 & 49.0 \\
\hline NuMex Sweetpak & 9.7 & 2.2 & 77.5 & 82 & 49.9 & 346 & 40.7 \\
\hline Texas Early White & 12.7 & 1.8 & 66.7 & 91 & 44.7 & 303 & 53.8 \\
\hline Mean & 6.3 & 2.1 & 75.0 & 89 & 52.4 & 330 & 44.4 \\
\hline $\operatorname{LSD}(5 \%)$ & $4.2^{* * * *}$ & $0.2^{* *}$ & NS & $5^{* * *}$ & $9.7^{*}$ & NS & $11.0^{* *}$ \\
\hline \multicolumn{8}{|c|}{ Fourth seeding (30 Sept.) } \\
\hline NuMex Mesa & 0.3 & 2.4 & 83.8 & 92 & 64.2 & 373 & 17.5 \\
\hline Daybreak & 0.6 & 2.4 & 90.4 & 91 & 62.1 & 380 & 37.5 \\
\hline NuMex Sweetpak & 3.0 & 2.6 & 88.3 & 83 & 63.3 & 402 & 37.5 \\
\hline Texas Early White & 1.7 & 1.9 & 72.5 & 91 & 52.0 & 323 & 42.5 \\
\hline Mean & 1.4 & 2.3 & 83.7 & 89 & 60.4 & 369 & 33.8 \\
\hline $\operatorname{LSD}(5 \%)$ & $1.3^{* *}$ & $0.2^{* * * *}$ & $8.9^{* *}$ & $4^{* * * *}$ & $7.0^{* *}$ & $27^{* * * *}$ & $7.5^{* *}$ \\
\hline
\end{tabular}

${ }^{2}$ The percentage of seedstalks was determined at harvest and calculated by dividing the number of plants with seedstalks by the total number of plants per plot.

yRoot systems of 30 bulbs per plot were rated based on a scale of 1 (no infected roots) to 9 (completely infected roots).

xPercentage of bulbs with pink root.

wPercentage of marketable yield was calculated by dividing marketable bulb weight by total bulb weight.

vuMarketable bulb yield was calculated by weighing the marketable bulbs per plot and adjusting the plot size to 1 ha.

"Average bulb weight was calculated by dividing the marketable bulb weight by the number of marketable bulbs.

the percentage of bulbs with single centers (single growing point) was determined by cutting each bulb transversely at the vertical center and measuring the number of growing points that extended $1.3 \mathrm{~cm}$ beyond the bulb's center.

Ns,*******NNonsignificant or significant at $P=0.05,0.01$, or 0.001 , respectively. 
than 'NuMex Mesa' and 'Texas Early White' at the second seeding but not the third seeding (Table 4).

At the first and second seeding dates, cultivars did not differ in their percentage marketable yield; however, 'NuMex Sweetpak' had a lower percentage marketable yield than the other cultivars at the third and fourth seeding dates (Table 4). At the earliest seeding date, marketable bulb yield was negatively correlated with bolting percentage (Table 4). Marketable yield decreased as the bolting percentage increased from 1.9\% ('NuMex Mesa') to $34.2 \%$ ('Texas Early White'). 'NuMex Mesa' and 'Daybreak' produced a greater marketable yield $\left(60.8\right.$ and $57.5 \mathrm{Mg} \cdot \mathrm{ha}^{-1}$, respectively) than 'Texas Early White'. At the second seeding date, 'Daybreak' produced at greater marketable yield than all of the other cultivars tested (Table 4). This likely resulted from a decrease in pink root incidence, and increases in bulb size and percentage marketable yield. At the third seeding date, 'NuMex Mesa' produced a greater marketable yield than 'NuMex Sweetpak' and 'Texas Early White' (Table 4). At the last seeding date, 'Texas Early White' had a lower marketable yield than the other cultivars. Across all cultivars, marketable bulb yield was greatest at the last seeding date.

At the first three seeding dates, average bulb weight was similar among cultivars tested (Table 4). At the last seeding date, 'Texas Early White' produced bulbs of a lighter weight than the other cultivars tested (Table 4). Across all cultivars, average bulb size was larger at the first and fourth seeding dates than at the second and third seeding dates (Table 4). At the first seeding dates, cultivars were similar in the percentage of single-centered bulbs that they produced (Table 4). At the other seeding dates, 'Texas Early White' produced a higher percentage of single-centered bulbs than 'NuMex Mesa' (Table 4). In a recent cultivar trial, 'Texas Early White' also produced a higher percentage of single centered bulbs than 'NuMex Mesa' (Cramer et al., 2002). Across all cultivars, the percentage of single-centered bulbs was lower at the last seeding date than the other seeding dates. The percentage of single centered bulbs is often negatively correlated with bulb size. As bulb size increases, the percentage of single centered bulbs decreases. Plants seeded on the last date tended to produce larger bulbs than plants seeded on the other dates.

Plants that were seeded on the first date were generally larger and had more leaves than plants seeded at later dates when measured at $90 \mathrm{~d}$ after seeding (Table 5). As the season progressed, plants that were seeded at later dates became comparable in plant height to plants seeded at the earliest seeding date. In addition, plants that were seeded later developed more leaves per plant than earlier seeded plants.

At the first seeding date, plants of 'NuMex Mesa' were shorter than plants of 'NuMex Sweetpak' at $90 \mathrm{~d}$ after seeding and were shorter than plants of all three cultivars at $120 \mathrm{~d}$ after seeding (Table 5). By $150 \mathrm{~d}$ after seeding, plants of 'NuMex Mesa' were comparable in height to plants of the other cultivars and this similarity in plant height remained for the rest of the growing season. At the second seeding, plants of 'NuMex Mesa' were shorter than plants of the other cultivars throughout the entire

Table 5. Plant height and leaf number of four fall-seeded cultivars seeded at four different dates and measured at five different dates after seeding.

\begin{tabular}{|c|c|c|c|c|c|c|c|c|c|c|}
\hline \multirow[b]{3}{*}{ Cultivar } & \multicolumn{5}{|c|}{ Plant ht $(\mathrm{cm})$} & \multicolumn{5}{|c|}{ Leaf no. } \\
\hline & \multicolumn{5}{|c|}{ Days after seeding } & \multicolumn{5}{|c|}{ Days after seeding } \\
\hline & 90 & 120 & 150 & 180 & 210 & 90 & 120 & 150 & 180 & 210 \\
\hline \multicolumn{11}{|l|}{ First seeding (9 Sept.) } \\
\hline NuMex Mesa & 20.8 & 19.7 & 23.1 & 38.3 & 69.8 & 3.8 & 3.4 & 3.9 & 5.8 & 8.4 \\
\hline Daybreak & 22.5 & 21.6 & 24.1 & 40.5 & 74.1 & 4.0 & 3.4 & 3.9 & 6.0 & 8.3 \\
\hline NuMex Sweetpak & 24.8 & 24.0 & 26.1 & 41.0 & 69.8 & 4.0 & 3.8 & 4.0 & 5.9 & 8.2 \\
\hline Texas Early White & 22.9 & 22.5 & 24.4 & 39.3 & 74.0 & 3.9 & 3.6 & 3.9 & 5.9 & 8.1 \\
\hline Mean & 22.7 & 22.0 & 24.4 & 39.8 & 71.9 & 3.9 & 3.5 & 3.9 & 5.9 & 8.3 \\
\hline $\operatorname{LSD}(5 \%)$ & $2.7^{*}$ & $2.1^{* *}$ & NS & NS & NS & NS & $0.2^{*}$ & NS & NS & NS \\
\hline \multicolumn{11}{|c|}{ Second seeding (16 Sept.) } \\
\hline NuMex Mesa & 15.9 & 15.7 & 20.7 & 37.1 & 66.4 & 3.3 & 3.0 & 3.6 & 5.8 & 7.8 \\
\hline Daybreak & 17.8 & 18.2 & 24.3 & 44.5 & 73.9 & 3.4 & 3.0 & 3.9 & 6.2 & 8.1 \\
\hline NuMex Sweetpak & 18.2 & 18.0 & 25.2 & 44.3 & 69.4 & 3.4 & 3.3 & 4.1 & 6.3 & 8.1 \\
\hline Texas Early White & 18.2 & 17.7 & 24.0 & 43.1 & 80.0 & 3.2 & 3.1 & 3.7 & 5.9 & 8.3 \\
\hline Mean & 17.5 & 17.4 & 23.5 & 42.2 & 72.4 & 3.3 & 3.1 & 3.8 & 6.0 & 8.1 \\
\hline $\operatorname{LSD}(5 \%)$ & $1.8^{*}$ & $1.6^{*}$ & $2.1^{* *}$ & $3.5^{* * * *}$ & $4.4^{* * * *}$ & NS & NS & $0.2^{* *}$ & NS & NS \\
\hline \multicolumn{11}{|l|}{ Third seeding (23 Sept.) } \\
\hline NuMex Mesa & 13.9 & 15.3 & 22.9 & 43.2 & 72.4 & 3.1 & 3.0 & 4.0 & 6.1 & 9.1 \\
\hline Daybreak & 15.4 & 16.8 & 26.0 & 46.5 & 74.7 & 3.2 & 3.0 & 4.0 & 6.2 & 8.7 \\
\hline NuMex Sweetpak & 16.2 & 17.6 & 26.2 & 47.5 & 69.0 & 3.0 & 3.2 & 4.0 & 6.4 & 8.6 \\
\hline Texas Early White & 16.3 & 17.6 & 25.9 & 44.9 & 78.0 & 3.2 & 3.1 & 3.8 & 6.1 & 8.4 \\
\hline Mean & 15.4 & 16.8 & 25.2 & 45.5 & 73.5 & 3.1 & 3.1 & 4.0 & 6.2 & 8.7 \\
\hline $\operatorname{LSD}(5 \%)$ & $1.3^{* *}$ & $1.6^{*}$ & $2.1^{*}$ & NS & $4.5^{* *}$ & NS & NS & NS & NS & NS \\
\hline \multicolumn{11}{|c|}{ Fourth seeding (30 Sept.) } \\
\hline NuMex Mesa & 12.9 & 14.1 & 23.8 & 52.5 & 70.8 & 2.6 & 2.9 & 4.2 & 6.6 & 9.2 \\
\hline Daybreak & 14.1 & 15.1 & 26.0 & 54.8 & 75.8 & 2.6 & 3.0 & 4.2 & 6.7 & 9.5 \\
\hline NuMex Sweetpak & 14.9 & 17.1 & 27.7 & 57.2 & 71.8 & 2.7 & 3.2 & 4.4 & 6.9 & 9.3 \\
\hline Texas Early White & 13.3 & 15.1 & 26.2 & 56.2 & 75.6 & 2.5 & 2.9 & 4.1 & 6.5 & 9.4 \\
\hline Mean & 13.8 & 15.3 & 25.9 & 45.5 & 73.5 & 2.6 & 3.0 & 4.2 & 6.7 & 9.4 \\
\hline $\operatorname{LSD}(5 \%)$ & NS & $1.2^{* * *}$ & $1.9^{* *}$ & $3.0^{*}$ & $3.8^{*}$ & NS & $0.2^{* *}$ & NS & NS & NS \\
\hline
\end{tabular}

ss,*,******Nonsignificant or significant at $P=0.05,0.01$, or 0.001 , respectively. 
length of the growing season. At the third seeding, plants of 'NuMex Mesa' were shorter than plants of the other cultivars when measured at 90, 120, and $150 \mathrm{~d}$ after seeding. Later in the growing season, plant height of 'NuMex Mesa' was not different from plant height of the other cultivars. At the fourth seeding, plants of 'NuMex Mesa' were shorter than plants of 'NuMex Sweetpak' when measured at 120,150, and $180 \mathrm{~d}$ after seeding (Table 5). In addition, plants of 'NuMex Mesa' were shorter than plants of 'Texas Early White' at 150, 180, and $210 \mathrm{~d}$ after seeding. Regardless of seeding date, plants of 'NuMex Mesa' had the same number of leaves as plants of the other cultivars when measured throughout the growing season. There were three instances in which plants of 'NuMex Mesa' had fewer leaves than plants of 'NuMex Sweetpak' (Table 5). These instances were randomly scattered between seeding dates and measuring dates.

The mechanism of bolting resistance is not known. Few studies on the inheritance of bolting resistance have been conducted. Bolting resistance may be highly additive since bolting resistant cultivars have been developed from bolting-susceptible germplasm using phenotypic recurrent selection in bolting-inducing selection environments. Several theories may explain the mechanism of bolting resistance. Bolting resistant plants may require a larger critical plant size than bolting susceptible plants in order to be receptive to a low temperature stimulus. Also, bolting resistant plants may require more chilling hours than bolting susceptible plants. With bolting resistant cultivars that have been developed by our program, earlier planting dates are required every three to four generations to produce the same level of bolting as in previous years with more bolting-susceptible cultivars. A high level of bolting is required during the selection process to make progress in bolting resistance. The absence of bolting-inducing low temperatures at the critical plant stage may also cause a lack of bolting. Bolting resistant plants may develop slower during the overwintering period than bolting susceptible plants such that smaller plants are produced during this period and these plants are not receptive to the low temperature stimulus for bolting. Our breeding program has had some concern in that selecting for bolting resistance, we may be selecting for weaker plants that do not produce a large plant size as compared to more vigorous plants that may bolt. Using both a bolting-resistant and a boltingsusceptible cultivar, Sanders and Cure (1996) found no difference in the growth rate of these two cultivars.

The mechanism of bolting resistance for 'NuMex Mesa' may be attributed to two factors. 'NuMex Mesa' produced shorter plants than bolting-susceptible cultivars (Table 5) at 90 and $120 \mathrm{~d}$ after seeding. These dates would be during the months of December and January when bolting-inducing temperatures would be present. These shorter plants of 'NuMex Mesa' would have a lower plant weight than plants of bolting-susceptible cultivars. However, 'NuMex Mesa' appears to grow at the same rate as bolting-susceptible cultivars due to a similar number of leaves being produced throughout the growing season (Table 5). 'NuMex Mesa' may also require a larger critical plant size to be receptive to bolting-inducing temperature as compared to bolting-susceptible cultivars. At the earliest seeding date, plants of 'NuMex Mesa' reached a height that was comparable to the height of bolting-susceptible cultivars at 150 and $180 \mathrm{~d}$ (Table 5), when bolting-inducing temperatures were still present. However, the susceptible cultivars bolted at this seeding date, while 'NuMex Mesa' did not (Table 4). The bolting resistance of 'NuMex Mesa' may be attributed to shorter plants or plants with less mass when bolting-inducing temperatures are present and/or greater critical plant size to be receptive to bolting-inducing temperatures as compared to bolting-susceptible cultivars.

In conclusion, earlier seeding dates resulted in larger plants with more leaves than later seeding dates when compared early in the growing season. By harvest time, plants from later seeding dates were comparable in height and had produced more leaves than earlier seeded plants. Plant height of 'NuMex Mesa' was less than plant height of bolting-susceptible cultivars. Bolting-resistant and bolting-susceptible cultivars produced a similar number of leaves throughout the season. Bolting incidence decreased as boltingsusceptible cultivars were seeded later. The mechanism of bolting resistance for 'NuMex Mesa' may be a smaller plant size at a time when a greater plant size is required for receptivity to bolting-inducing temperatures (as compared to bolting-susceptible cultivars). Bulb maturity was delayed with a delay in seeding. Disease incidence was not well correlated with seeding date. For bolting-susceptible cultivars, a greater marketable yield was obtained when seeding was delayed. The largest bulb size was not always obtained from the earliest seeding (because of disease pressures). The percentage of single-centered bulbs was inversely proportional to bulb size but not well correlated with seeding date.

\section{Literature Cited}

Allen, E.J., J.L. Jones, and P.J. Salter. 1978. Effects of date of sowing on overwintered onion varieties in Pembrokeshire. J. Agr. Sci. Camb. 90:237-239.

Almanza-Sandoval, J.L. and M.M. Wall. 2000. Maturity date induced by transplant size or sowing date affects pungency of NuMex sweet onions, p. 189-191. In: W. Randle (ed.). Proc. 3rd Intl. Symp. Edible Alliaceae. Alliums 2000. Athens, Ga.

Brewster, J.L. 1983. Effect of photoperiod, nitrogen nutrition and temperature on inflorescence initiation and development in onion (Allium серa L.) Ann. Bot. 51:429-440.

Brewster, J.L. 1985. The influence of seedling size and carbohydrate status of photon flux density during vernalization on inflorescence initiation in onion (Allium cepa L.). Ann. Bot. 55:403-414.

Brewster, J.L. 1987. Vernalization in the onion-A quantitative approach, p. 171-183. Proc. 45 $5^{\text {th }}$ Easter School Agr. Sci., Manipulation of flowering. Butterworths, London.

Brewster, J.L. and S.J. Salter. 1980. The effect of plant spacing on the yield and bolting of two cultivars of overwintered bulb onions. J. Hort. Sci. 55:97-102.

Corgan, J.N. 1996. 'NuMex Mesa' onion. N.M. Agr. Expt. Sta. Var. Rel. Not.

Corgan, J.N., M.M. Wall, C.S. Cramer, T. Sammis, B. Lewis, and J. Schroeder. 2000. Bulb onion culture and management. N.M. Coop. Ext. Serv. Circ. 563.

Cramer, C.S., J.N. Corgan, J.L. Mendoza, and M.M. Wall. 2000. 19981999 Onion variety trials at New Mexico State University. N.M. Agr. Expt. Sta. Res. Rpt. 739.

Cramer, C.S., J.L. Mendoza, and M.M. Wall. 2002. 2000-2001 Onion variety trials at New Mexico State University. N.M. Agr. Expt. Sta. Res. Rpt. 748.

Cramer, C.S., J.L. Mendoza, and J.N. Corgan. 1998. Fall-planted onion variety trials at New Mexico State University, p. 299-312. In: R.E. Voss (ed.). Proc. 1998 Natl. Onion (and other Allium) Res. Conf. Veg. Res. Info. Ctr., Univ. Calif., Davis, Calif.

Cramer, C.S., J.N. Corgan, J.L. Mendoza, and M.M. Wall. 2001. 19992000 Onion variety trials at New Mexico State University. N.M. Agr. Expt. Sta. Tech. Rpt. 38.

Gregory, F.G. 1936. The effect of length of day on the flowering of plants. Sci. Hort. 4:143-154

Hartsema,A.M. 1947. The periodic development of Allium cepa L. "Giant Zittau". Meded. Landbouwhogesch. Wageningen 48:265-301.

Heath, O.V.S. and P.B. Mathur. 1944. Studies in the physiology of the onion plant. II. Inflorescence initiation and development, and other 
changes in the internal morphology of onion sets, as influenced by temperature and day length. Ann. Appl. Biol. 31:173-186.

Heath, O.V.S., M. Holdsworth, M.A.H. Tincker, and F.C. Brown. 1947. Studies in the physiology of the onion plant. III. Further experiments on the effects of storage temperature and other factors on onions grown from sets. Ann. Appl. Biol. 34:473-502.

Holdsworth, M. 1945. A comparative study of onion varieties in relation to bolting and yield when grown from sets. Ann. Appl. Biol. 32:22-34.

Ito, K. 1956. Studies on the bolting of the onion. I. Relation between flower bud formation and bulb division. J. Jpn. Soc. Hort. Sci. 25:47-53.

Jones, H.A. and S.L. Emsweller. 1937. Effect of storage, bulb size, spacing, and time of planting on production of onion seed. Calif. Agr. Exp. Sta. Bul. 628.

Matlob,A.N. and M.T. El-Haber. 1979. The effect of set sizes and planting dates on bolting and yield of onion cv. Baashekaa. 51-61.

Moursi, M.A., K.M. El-Habbasha, and N.A. Nour. 1975. Effect of sowing date and seed rate on the growth and yield of direct sown onion (Allium cepa L.) plants. Egypt. J. Hort. 2:243-256.

Passam, H.C., C.M. Olympios, and K. Akoumianakis. 1995. Definition of the optimum sowing date for the cultivation of short-day onion cultivars in Greece. Allium Improv. Nwsl. 5:44-47.

Rabinowitch, H.D. 1979. Doubling of onion bulbs as affected by size and planting date of sets. Ann. Appl. Biol. 93:63-66.

Rabinowitch, H.D. 1990. Physiology of flowering, p. 113-134. In: J.L. Brewster and H.D. Rabinowitch (eds.). Onions and allied crops, vol. I. CRC Press, Boca Raton, Fla.

Richwine, P.A. 1990. Effect of fall planting date on bulb yield of 'Sweet Winter' onion in the rolling plains of Texas. HortScience 25:981.

Salter, P.J. and J.M. James. 1975. The performance of Japanese and European cultivars of onions from autumn sowing for early production. J. Natl. Inst. Agr. Bot. 13:367-379.

Sanders, D.C. and J.D. Cure. 1996. Control of bolting in autumn-sown sweet onions through undercutting. J. Amer. Soc. Hort. Sci. 12: 1147-1151.

Thompson, H.C. and O. Smith. 1938. Seedstalk and bulb development in the onion (Allium cepa L.). Agr. Expt. Sta. Cornell Univ. Bul. 708.

U.S. Department of Agriculture. 2000. Vegetables. 1999 Summary. Vg 1-2 (00). U.S. Govt. Printing Office, Wash., D.C.

Wall, M.M. and J.N. Corgan. 1999. NuMex Sweetpak onion. HortScience 34:1303-1304. 